\title{
Control of freshwater fish louse Argulus coregoni: a step towards an integrated management strategy
}

\author{
Teija Hakalahti-Sirén ${ }^{1, *}$, Viktor N. Mikheev $^{2}$, E. Tellervo Valtonen ${ }^{1}$
}

${ }^{1}$ Department of Biological and Environmental Science, PO Box 35 (ya), University of Jyväskylä, 40014 Jyväskylä, Finland

${ }^{2}$ A.N. Severtsov Institute of Ecology \& Evolution, Russian Academy of Sciences, 33 Leninskii Prospekt, 119071 Moscow, Russia

\begin{abstract}
Harmful infections by ectoparasites of the genus Argulus occur repeatedly in freshwater fish farming operations where the management has largely been ineffective. Preventative methods and regular monitoring are rarely applied, so that chemical interventions become necessary. According to the Integrated Pest Management (IPM) approach, a sustainable management or control program for a parasite should be based on knowledge of the ecology of the parasite along with adoption of several prevention and control methods, the application of which is dependent upon the prevailing infection level. The application of multiple management tactics is especially important because parasites can develop resistance to chemical treatments. We took a step towards sustainable management of Argulus populations and tested the effect of several types of treatments on survival of $A$. coregoni at different stages in its life cycle. Parasite juveniles and adults were highly sensitive to potassium permanganate treatments $\left(0.01 \mathrm{~g} \mathrm{l}^{-1}\right)$, which lead to $100 \%$ mortality, whereas treatments with formalin $\left(0.6 \mathrm{ml} \mathrm{l}^{-1}\right)$, sodium chloride $\left(20 \mathrm{~g} \mathrm{l}^{-1}\right)$ or malachite-green/formalin were not effective. Mechanical treatment by shaking infected fish in a hand net was an effective means of detaching parasites from the fish, and resulted in $>80 \%$ decreases in parasite numbers. Compared to eggs in control treatments, both drying over a minimum period of $24 \mathrm{~h}$ and formalin treatments $\left(120 \mathrm{ml} \mathrm{l}^{-1}\right)$ led to significantly higher mortality of $A$. coregoni eggs. Other treatments, i.e. drying over a period of $15 \mathrm{~h}$, baths in potassium permanganate $\left(1 \mathrm{~g} \mathrm{l}^{-1}\right)$ or sodium chloride $\left(50 \mathrm{~g} \mathrm{l}^{-1}\right)$, did not significantly affect the viability of eggs. Based on the present results and previously published papers, we present an initial framework showing how $A$. coregoni populations could be managed effectively.
\end{abstract}

KEY WORDS: Integrated pest management $\cdot \mathrm{IPM} \cdot \mathrm{Control} \cdot$ Prevention $\cdot$ Parasite $\cdot$ Argulus coregoni . Fish louse

\section{INTRODUCTION}

Intensification of aquaculture has lead to the development of favourable conditions for a variety of fish disease-causing agents (Rintamäki et al. 1994, Rintamäki-Kinnunen \& Valtonen 1997, Suomalainen et al. 2005, Karvonen et al. 2006), crustacean ectoparasites among others (Menezes et al. 1990, Hakalahti \& Valtonen 2003, Costello 2006). Parasitic crustaceans are epithelial browsers that harm the protective epithelium of the fish and evoke stress responses by attaching and feeding on fish skin or gills. The epithelial damage and other stressor-induced changes in fish physiology increase fish susceptibility to secondary diseases (see Mustafa et al. 2000, Tully \& Nolan 2002, Bandilla et al. 2006). Therefore, fish parasitized by ectoparasites often have a simultaneous fungal or bacterial infection (Cusack \& Cone 1986, Bakke \& Harris 1998, Bandilla et al. 2006). At commercial farms, ectoparasitic infections of fish result in stunted growth, reduced survival and increased production costs (Menezes et al. 1990, Costello 2006).

Fish farmers combat crustacean ectoparasites using a variety of methods that are either laborious, expen- 
sive or both, and do not always prevent economic losses. The majority of management protocols have relied on the use of chemicals either as oral medications or bath treatments (e.g. Costello 1993, 2006). For example, the in-feed medication SLICE $^{\circledR}$ (emamectin benzoate; Schering-Plough Animal Health) has been used to control many crustaceans, e.g. Lepeoptheirus salmonis in seawater aquaculture, Salmincola edwardsii and Argulus coregoni in freshwater aquaculture (Stone et al. 2000, Duston \& Cusack 2002, Hakalahti et al. 2004a). Alternative methods are, for example, fallowing farm sites between stockings (Bron et al. 1993), use of cleaner fishes (Treasurer 2002) and removal of specific life-cycle stages from the parasite populations (Gault et al. 2002, Hakalahti et al. 2004b). The emergence of reduced sensitivity to chemical treatments with increased doses applied to control parasites, however, has lead to concerns about the sustainability of the industry (e.g. Jones et al. 1992), and consequently to the adoption of the Integrated Pest Management (IPM) concept into aquaculture (e.g. Sommerville 1998, Mordue (Luntz) \& Pike 2002). An IPM program is typically based on several practises including prevention of infections, monitoring infection levels, using thresholds for action and finally implementing different types of control tactics. The IPM is credited with better and longer-term control efficacy due to decreased potential for the evolution of resistance to chemicals (Hoy 1998). IPM-based practises have been developed and applied in the control of marine parasitic copepods such as Lepeophtheirus salmonis (Sommerville 1998, Mordue (Luntz) \& Pike 2002); however, studies on management of crustaceans in freshwaters are rare.

Fish lice of the genus Argulus cause frequent problems for northern inland fish farming (Shimura 1983, Hakalahti \& Valtonen 2003, Taylor et al. 2006). A. foliaceus (Linné 1758) is a common generalist species in Finland (Mikheev et al. 1998), whereas A. coregoni (Thorell 1865) occurs primarily on salmonids, and occasionally infects other fish genera such as cyprinids (Shimura 1983, Pasternak et al. 2004). The present study concentrated mainly on $A$. coregoni. This parasite has a direct life cycle including eggs, free-living infective larvae, and juvenile and adult stages on fish (Shimura 1981). In Finland, the larvae typically emerge in May from over-wintered A. coregoni eggs (Hakalahti \& Valtonen 2003, Hakalahti et al. 2006). Although strongly affected by water temperatures, the life cycle of $A$. coregoni is typically completed within $1.5 \mathrm{mo}$ at Finnish summer temperatures (Hakalahti \& Valtonen 2003, Hakalahti et al. 2006). Females deposit their eggs on hard substrata such as stones and then they die (Mikheev et al. 2001, Hakalahti et al. 2004b). The negative impact of Argulus spp. for a fish is a combined effect of parasitic feeding and secondary infections, either from opportunistic microbes present in the water (Singhal et al. 1990, Rahman 1996, Bandilla et al. 2006) or from pathogens spreading among hostswitching parasite individuals (Cusack \& Cone 1986, Bandilla et al. 2008).

The objective of the present study was to create a framework for sustainable management of Argulus coregoni populations using components of the IPM concept. Some fish farmers in Finland have used the in-feed medication SLICE ${ }^{\circledR}$ to reduce Argulus levels (Hakalahti et al. 2004a). Simulations of a recent population dynamic model of $A$. coregoni, however, show that the parasite 'egg-bank' consisting of eggs with variable timings of emergence over several years (see Hakalahti et al. 2004c) acts as an effective buffer against such control practises (Fenton et al. 2006). Therefore, repeated SLICE ${ }^{\circledR}$ treatments are needed to suppress an outbreak, creating a potential for resistance development. Rapid development of resistance to the insecticide lindane among exposed Argulus populations has already been demonstrated (Lahav et al. 1962). An alternative method comprising removal and destruction of any eggs laid on submerged artificial egg-laying substrata has been tested (Hakalahti et al. 2004b), but not yet been applied at operational farms. Thus, there is an urgent need to further develop management of Argulus populations (see also Taylor et al. 2006). The specific aims of the present study were to: (1) test several types of methods (chemical, biological and mechanical) to prevent and control A. coregoni infestations, (2) pinpoint the most vulnerable stages in the parasite life cycle against which the specific control attempts could be targeted, and (3) based on the present results and previously published work, create a framework for sustainable management of $A$. coregoni populations.

The chemicals used were sodium chloride, formalin, potassium permanganate and a malachite-green/formalin mixture, all of which are or have been common treatments against ectoparasites in Finnish fish farming (Rintamäki et al. 1994, Rintamäki-Kinnunen \& Valtonen 1997). Although the use of malachite-green is banned in most European countries (from 1 October 2001 onwards in Finland), it was included owing to its traditional and most effective use as a bath treatment against ectoparasitic ciliate and fungal infections such by Ichthyophthirius multifiliis and Saprolegnia spp., respectively (Willoughby \& Roberts 1992, RintamäkiKinnunen et al. 2005a). If malachite-green/formalin has a negative effect on attached fish lice, the ban on its use may explain the increase in Argulus problems in the current century. In addition to chemical procedures, drying was also tested as a method to eradicate A. coregoni eggs. Mechanical handling of fish has 
been suggested by fish farmers to have some utility in dislodging attached ectoparasitic crustaceans. This was tested in an experiment performed under farming conditions where infected fish were shaken in hand nets.

\section{MATERIALS AND METHODS}

Selection of effective chemicals for control of parasites attached to fish. The effects of 4 different chemical treatments were tested on survival of Argulus coregoni under laboratory conditions. These chemicals have traditionally been employed at Finnish fish farms for managing various ectoparasites (Rintamäki et al. 1994, Rintamäki-Kinnunen \& Valtonen 1997). Two concentrations of each chemical were tested; dosing choices were based on the treatment ranges used in Finnish fish farming (e.g. Rintamäki et al. 1994, Rintamäki-Kinnunen \& Valtonen 1997, RintamäkiKinnunen et al. 2005a,b). The chemicals and their concentrations were: (1) formalin 0.6 and $0.4 \mathrm{ml} \mathrm{l}^{-1}$, (2) salt $(\mathrm{NaCl}) 20$ and $15 \mathrm{~g} \mathrm{l}^{-1}$, (3) potassium permanganate $\left(\mathrm{KMnO}_{4}\right) 1.2$ and $0.9 \mathrm{~g} \mathrm{l}^{-1}$, and (4) malachite green/formalin (3.7 $\mathrm{g}$ of malachite green mixed in $1 \mathrm{l}$ formalin) 0.025 and $0.0125 \mathrm{ml} \mathrm{l}^{-1}$. Filtered lake water was used in the controls, giving 9 treatments in total. Each treatment was replicated 4 times. Each experiment was repeated with 2 different juveniles and one adult $A$. coregoni stage. Their mean body lengths, which were measured on formalin-preserved individuals $(\mathrm{n}=360)$ after the experiments, were $1.1 \pm 0.13( \pm \mathrm{SD}), 2.9 \pm 0.40$ and $7.5 \pm 0.40 \mathrm{~mm}$, respectively.

The experiments were performed in plastic containers each filled with $250 \mathrm{ml}$ of freshly prepared chemical solution and 10 parasites. Parasites needed in the experiments were collected from rainbow trout Oncorhynchus mykiss (30 to $40 \mathrm{~cm}$ total length) at a fish farm. To collect the parasites, captured fish were anesthetized with MS-222 (3-aminobenzoic acid ethyl ester). Parasites collected were maintained and monitored in an aerated aquarium over $1 \mathrm{~d}$ (temperature $21 \pm 1^{\circ} \mathrm{C}$ ), and only parasites that were swimming actively and apparently in good condition were used in the experiments. At the start of each trial, parasites were randomly picked out from the holding aquarium and introduced to experimental containers using pipettes filled with a minimum amount of water (to reduce dilution of the chemicals). Parasite survival in each container was monitored under laboratory conditions (temperature $21 \pm 1^{\circ} \mathrm{C}$ ) by counting and collecting dead parasites after $15 \mathrm{~min}, 30 \mathrm{~min}, 1 \mathrm{~h}, 2 \mathrm{~h}, 4 \mathrm{~h}$ and $16 \mathrm{~h}$ from the start of the experiment. Parasite deaths were confirmed by gently prodding individuals with a needle.
Equalities of mean life times between replicate containers were tested with ANOVA; no differences were found between containers in any of the treatments ( $p>$ 0.05 in all cases). The data were checked for homogeneity of variances and for normality. Data were then analyzed with a nonparametric survival analysis whose survival functions were estimated using the Kaplan-Meier life-table method (Lee 1992).

Minimum effective concentration and duration of potassium permanganate treatment. Since potassium permanganate was found to be lethal to Argulus coregoni (see results of the experiment described in the section 'Selection of effective chemicals for control of parasites attached to fish'), its minimum effective concentration was determined in further experiments. Treatments with potassium permanganate concentrations of $0.01,0.005,0.001$ and $0.0001 \mathrm{~g} \mathrm{l}^{-1}$ were applied. The experimental set-up was similar to the experiment described in the previous section; 4 different $A$. coregoni developmental stages were used and the number of replicate containers was 3. Parasite mortality was followed more often: after $15 \mathrm{~min}, 30 \mathrm{~min}$, $1 \mathrm{~h}, 2 \mathrm{~h}, 4 \mathrm{~h}, 5 \mathrm{~h}, 7 \mathrm{~h}, 16 \mathrm{~h}$ and $24 \mathrm{~h}$ from the start of the experiment. The average body lengths of the parasites $(\mathrm{n}=150)$ in the experiments were $0.8 \pm 0.2( \pm \mathrm{SD}), 2.3 \pm$ $0.3,6.6 \pm 0.5$ and $10.3 \pm 0.6 \mathrm{~mm}$. Filtered lake water was used in controls. Since potassium permanganate concentrations of 0.001 and $0.0001 \mathrm{~g} \mathrm{l}^{-1}$ did not affect parasite survival, additional concentrations of 0.004 , 0.003 and $0.002 \mathrm{~g} \mathrm{l}^{-1}$ were tested on parasites in size classes 6.6 and $10.3 \mathrm{~mm}$. Equalities of mean life times between replicate containers were tested with ANOVA; no differences were found between the containers in any treatment ( $p>0.05$ in all cases). The data were checked for homogeneity of variances and for normality. Data were then analyzed with Cox regression analysis using parasite size class and potassium permanganate concentration as covariates (Lee 1992).

The minimum duration of chemical treatment was determined at a potassium permanganate concentration of $0.01 \mathrm{~g} \mathrm{l}^{-1}$ since this concentration was found to be the minimum concentration leading to $100 \%$ mortality of exposed Argulus coregoni. Parasites were exposed to potassium permanganate as in previous experiments (4 replicate containers, 10 adult parasites in each), but after $30 \mathrm{~min}$ or $1 \mathrm{~h}$ from the start of the exposure, parasites were removed from the container with a pipette and transferred to clean water containers where their survival was followed over a period of $24 \mathrm{~h}$. Controls (4 replicates) were kept in clean lake water throughout.

Mechanical treatments. Mechanical treatments of Argulus-infested fish were tested as a method for detaching and removing parasites. Vigorous, brief shakings (20 to $30 \mathrm{~s}$ ) were given to fish using a hand 
net in a water tank. The treatment was performed in 2 earth-lined fish ponds containing either A. coregoniinfected rainbow trout Oncorhynchus mykiss (mean fork length $35 \mathrm{~cm} \pm 2.5 \mathrm{SD}, \mathrm{n}=10$ ) or brown trout Salmo trutta $(13 \mathrm{~cm} \pm 0.9, \mathrm{n}=14)$. Brown trout had concurrent infections with $A$. coregoni and A. foliaceus. Fish in each pond were treated differently; salted water $\left(\mathrm{NaCl}, 0.05 \mathrm{~g} \mathrm{l}^{-1}\right)$ was used in the treatment of rainbow trout and lake water was used in the treatment of brown trout. Hundreds of fish in both ponds were treated and were subsequently transferred to empty ponds. The experiment was performed under farming conditions by the fish farmer, which restricted our ability to implement the experimental design.

During the treatment, groups of fish consisting of 2 to 4 individuals were captured and shaken together in a hand net. After treatment, numbers of detached parasites in the water and the numbers of parasites remaining on the fish were counted and removed. To count attached parasites, fish were narcotized with MS-222. These samples were taken in total from 10 randomly chosen rainbow trout treated in salted water and from 14 brown trout treated in lake water, respectively. Further groups of 14 and 10 randomly chosen brown trout were individually captured from the pond immediately before treatment in lake water and a day following their treatment, respectively. Captured fish were narcotized (MS-222) and the number of Argulus coregoni and $A$. foliaceus were counted from each fish. Fish were released back to the pond after sampling.

To evaluate the selectivity of mechanical treatment by parasite sex and size, samples of Argulus coregoni removed from rainbow trout during the experiment (mechanical treatment in salted water) were preserved in $5 \%$ formalin for further analysis. The pre-treatment sample consisted of $2 \mathrm{~A}$. coregoni infrapopulations (pooled sample from 2 fish), while the post-treatment sample consisted of 10 parasite infrapopulations totalling 409 and 426 fish lice, respectively. Parasite sex and body length, which was measured from the anterior edge of the carapace to the end of the parasite abdominal lobes, were determined under a dissecting microscope (see Shimura 1983).

Selection of methods for controlling parasite eggs. Effects of various treatments under laboratory conditions were tested on hatching success of Argulus coregoni eggs. Five different types of treatments were used consisting of 3 chemical treatments and various drying periods. The treatments were: (1) potassium permanganate $\left(\mathrm{KMnO}_{4}\right) 1 \mathrm{~g} \mathrm{l}^{-1}$, (2) salt (NaCl) $50 \mathrm{~g} \mathrm{l}^{-1}$, (3) formalin $120 \mathrm{ml} \mathrm{l}^{-1}$, (4) formalin $120 \mathrm{ml} \mathrm{l}^{-1}$ applied to dried eggs $(15 \mathrm{~h})$, and (5) drying periods of 15,24 , 48 and 96 h. Filtered lake water was used in controls and each treatment was replicated 5 times, giving 9 treatments in total. We tested the effect of each treat- ment on the viability of parasite eggs collected from a commercial fish farm on 25 April 1999 (Set A). As the drying period of $15 \mathrm{~h}$ did not significantly affect the hatching rate of $A$. coregoni eggs compared to the control, additional longer drying periods $(24,48$ or $96 \mathrm{~h}$ ) were tested on parasite eggs collected on 29 May 2001 (Set B). Separate control treatments were used for each set of eggs.

During the experiments, several randomly chosen stones with attached Argulus coregoni egg clutches were exposed to each chemical (freshly prepared with lake water) for over $15 \mathrm{~h}$ or were allowed to dry. After the treatment periods, stones were rinsed in lake water, and egg clutches were carefully scraped off the stones. Samples of eggs (about $5 \mathrm{~cm}^{2}$ area filled with eggs) were taken from each stone and transferred to plastic containers filled with $200 \mathrm{ml}$ of lake water. Water in each container was changed, and hatched larvae were removed and counted daily over a period of $9 \mathrm{~d}$. During the experiments with Set $\mathrm{A}$ and $\mathrm{B}$ eggs, daily water temperatures in the experimental containers were $17.5^{\circ} \mathrm{C}( \pm 0.5)$ and $21^{\circ} \mathrm{C}$ $( \pm 0.5)$, respectively.

\section{RESULTS}

\section{Selection of effective chemicals for control of parasites attached to fish}

Both concentrations of potassium permanganate tested $\left(0.012\right.$ and $\left.0.009 \mathrm{~g} \mathrm{l}^{-1}\right)$ led to $100 \%$ mortality among Argulus coregoni within 16 h (Fig. 1). Mortality rates of parasites belonging to size groups $1.1 \mathrm{~mm}$ (log-rank test for potassium permanganate concentration $0.009 \mathrm{~g} \mathrm{l}^{-1}$ : chi-squared test $\left.\chi^{2}=75.61, \mathrm{p}<0.001\right)$, $2.9 \mathrm{~mm}\left(\chi^{2}=75.648, \mathrm{p}<0.001\right)$ and $7.5 \mathrm{~mm}\left(\chi^{2}=\right.$ 77.36, $\mathrm{p}<0.001)$ were higher in potassium permanganate solutions than in controls (Fig. 1). A malachite green/formalin mixture at $0.025 \mathrm{ml} \mathrm{l}^{-1}$ led to increased mortality rates only among parasites in size group of $2.9 \mathrm{~mm}\left(\chi^{2}=10.01, \mathrm{p}=0.002\right.$, Fig. 1), whereas the effect of the lower concentration $\left(0.0125 \mathrm{ml} \mathrm{l}^{-1}\right)$ was non-significant in this size class $\left(\chi^{2}=1.00, p=0.317\right)$. Parasite survival in both sodium chloride and formalin solutions and in controls, was $100 \%$ (Fig. 1).

\section{Minimum effective concentration and duration of potassium permanganate baths}

Both potassium permanganate concentration (Cox regression: Wald $=309.99, \mathrm{p}<0.001$ ) and parasite size (Wald $=95.68, \mathrm{p}<0.001$ ) affected survival of Argulus 

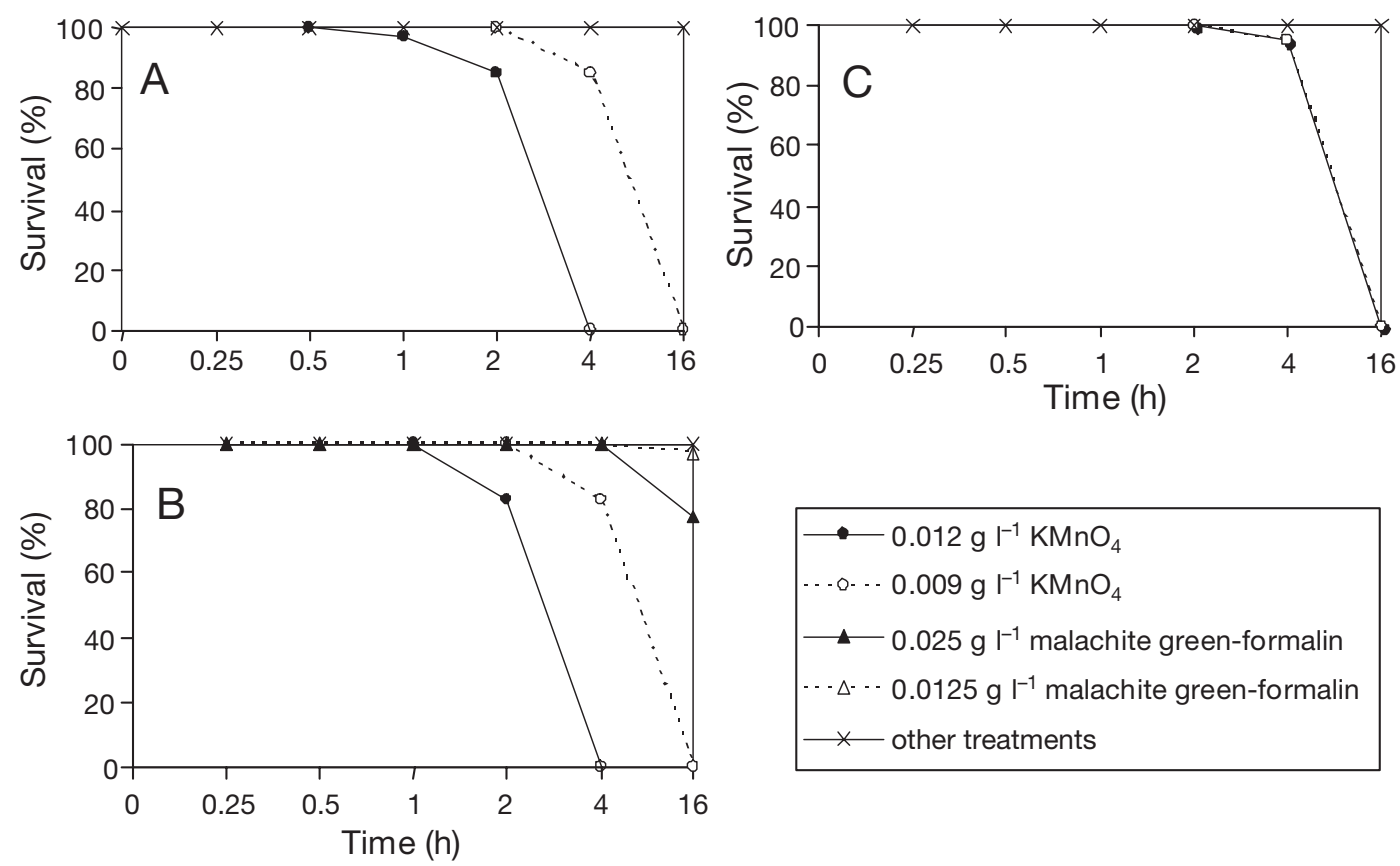

Fig. 1. Argulus coregoni. Survival of (A) juveniles (mean length $1.1 \mathrm{~mm})$, (B) juveniles $(2.9 \mathrm{~mm})$ and $(\mathrm{C})$ adults $(7.5 \mathrm{~mm})$ exposed to various chemical solutions. Treatments labelled 'other treatments' are salted water $\left(\mathrm{NaCl}, 15\right.$ or $\left.20 \mathrm{~g} \mathrm{l}^{-1}\right)$, formalin $(0.17$ or $0.25 \mathrm{ml} \mathrm{l}^{-1}$ ) and control in lake water

coregoni (Table 1). Parasite death rate and potassium permanganate concentration had a positive association (Fig. 2, Table 1). In general, the death rate was highest for juveniles (size class $2.3 \mathrm{~mm}$ ); the risk of death in this size class was 3.6-fold higher than for adult parasites (size class 10.3 mm; Fig. 3, Table 1). The risk of death among exposed small parasite juveniles (size class $0.8 \mathrm{~mm})$, however, was only 1.83-fold higher than for adult parasites (Fig. 3, Table 1).

All parasites that were exposed to potassium permanganate $\left(0.01 \mathrm{~g} \mathrm{l}^{-1}\right)$ for over $30 \mathrm{~min}$ or $1 \mathrm{~h}$ periods of time and then transferred to clean water died within $24 \mathrm{~h}$, whereas the survival of parasites in control containers kept in clean water was $100 \%$.

\section{Mechanical treatments}

Eighty-one percent of Argulus coregoni were detached from rainbow trout by shaking fish ( 2 to 4 fish at a time) with a hand net in a salted water container. Similar treatments of brown trout in fresh water resulted in an $82.4 \%$ reduction in A. foliaceus and an $86.7 \%$ reduction in A. coregoni numbers immediately after the treatments. Note that statistical comparison between the methods is not possible, because different fish species were used. The day following the treatment (mechanical treatment in fresh water), A. foliaceus infection levels recorded on brown trout individually captured from the fish pond were lower than before the treatment (MannWhitney test: $U=17.00, \mathrm{p}=0.002$, Fig. 4). The effect of the treatment on $A$. coregoni numbers on brown trout was non-significant $(U=39.00, \mathrm{p}=0.051)$, although a tendency towards decreased infection levels was apparent (Fig. 4).

Before the mechanical treatment (salted water) was applied, the Argulus coregoni sex ratio on rainbow trout was balanced (chi-square test: $\mathrm{n}=2312, \chi^{2}=$

Table 1. Argulus coregoni. Impacts of parasite size and potassium permanganate concentration on survival as assessed by Cox regression analysis. The parasite size class $10.3 \mathrm{~mm}$ and potassium permanganate concentration $0.01 \mathrm{~g} \mathrm{l}^{-1}$ were used as reference categories for statistical comparisons

\begin{tabular}{|lccccc|}
\hline Variable & $\begin{array}{c}\text { Regression } \\
\text { coefficient }\end{array}$ & SE & Wald & $p$ & $\begin{array}{c}\text { Hazard } \\
\text { ratio }\end{array}$ \\
\hline Size class (mm) & & & 95.68 & $<0.001$ & \\
0.8 & 0.06 & 0.166 & 13.33 & 0.003 & 1.83 \\
2.3 & 1.29 & 0.160 & 64.76 & $<0.001$ & 3.62 \\
6.6 & -0.18 & 0.127 & 1.90 & 0.168 & 1.08 \\
Concentration $\left(\mathbf{g ~ l}^{-\mathbf{1}}\right)$ & & 309.99 & $<0.001$ & \\
0.005 & -1.30 & 0.119 & 119.65 & $<0.001$ & 0.27 \\
0.004 & -1.70 & 0.168 & 102.83 & $<0.001$ & 0.18 \\
0.003 & -2.27 & 0.196 & 134.22 & $<0.001$ & 0.10 \\
0.002 & -4.29 & 0.396 & 116.25 & $<0.001$ & 0.01 \\
0.001 & -7.76 & 1.008 & 59.33 & $<0.001$ & $4.25 \times 10^{-4}$ \\
\hline
\end{tabular}




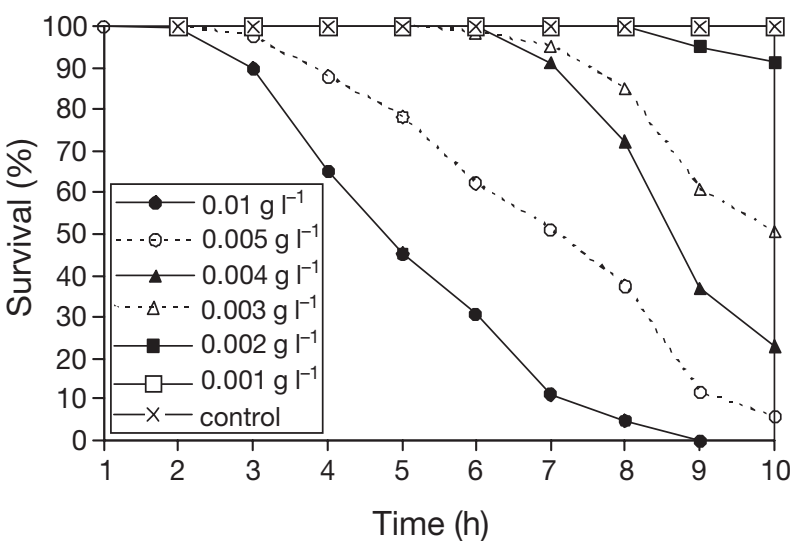

Fig. 2. Argulus coregoni. Survival of individuals (all size classes combined) exposed to various potassium permanganate concentrations

0.42, df $=1, \mathrm{p}=0.517$; Fig. 3), but became strongly male-biased after the treatment $\left(\mathrm{n}=426, \chi^{2}=31.04\right.$, $\mathrm{p}<0.001$ ) (Fig. 5). Only $12.3 \%$ of initial number of females remained attached to fish, while $23.9 \%$ of males were left. Also, the average body lengths of female (Mann-Whitney test: $U=11809, \mathrm{p}<0.001$ ) and

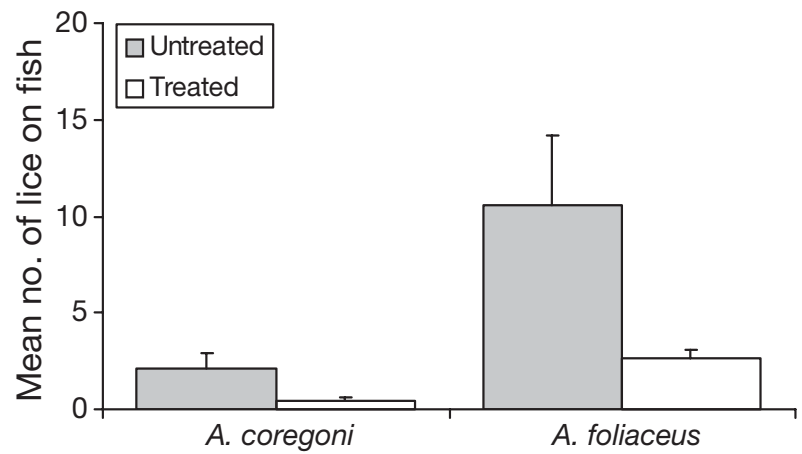

Fig. 4. Argulus coregoni and A. foliaceus. Mean (+1 SE) numbers on fish before and $1 \mathrm{~d}$ after mechanical treatment of brown trout Salmo trutta. During the treatment, fish were rapidly shaken in a freshwater container with a hand net, then released back into a fish pond

male $(U=21848, \mathrm{p}<0.001)$ A. coregoni individuals attached to fish decreased as a result of the treatment. The average body lengths of attached $A$. Coregoni females and males decreased from $9.1 \pm 2.22( \pm \mathrm{SD})$ to $8.1 \pm 2.65 \mathrm{~mm}$ and from $9.5 \pm 2.36$ to $9.2 \pm 2.01 \mathrm{~mm}$, respectively.
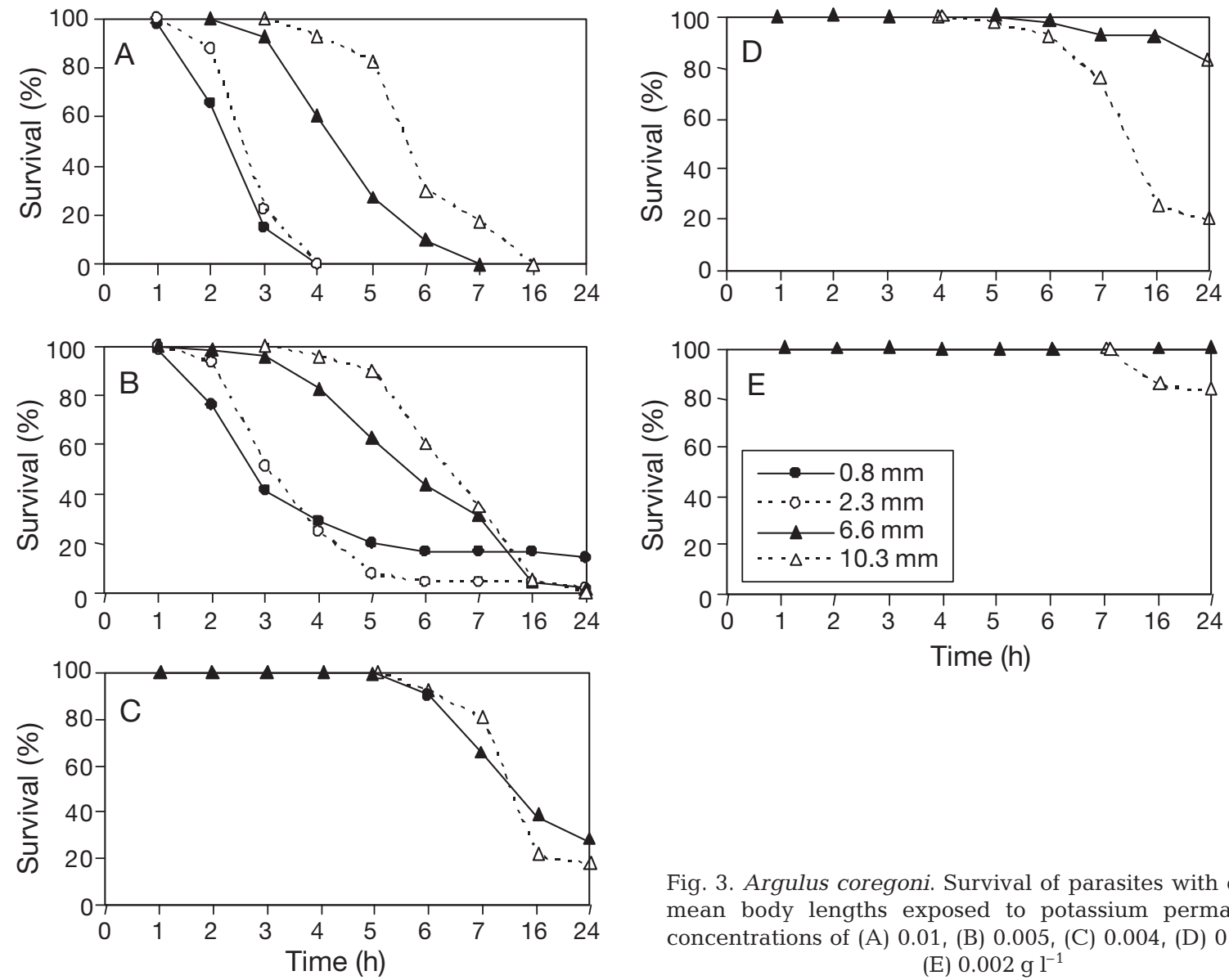

Fig. 3. Argulus coregoni. Survival of parasites with different mean body lengths exposed to potassium permanganate concentrations of (A) 0.01, (B) 0.005, (C) 0.004, (D) 0.003 and (E) $0.002 \mathrm{~g} \mathrm{l}^{-1}$ 


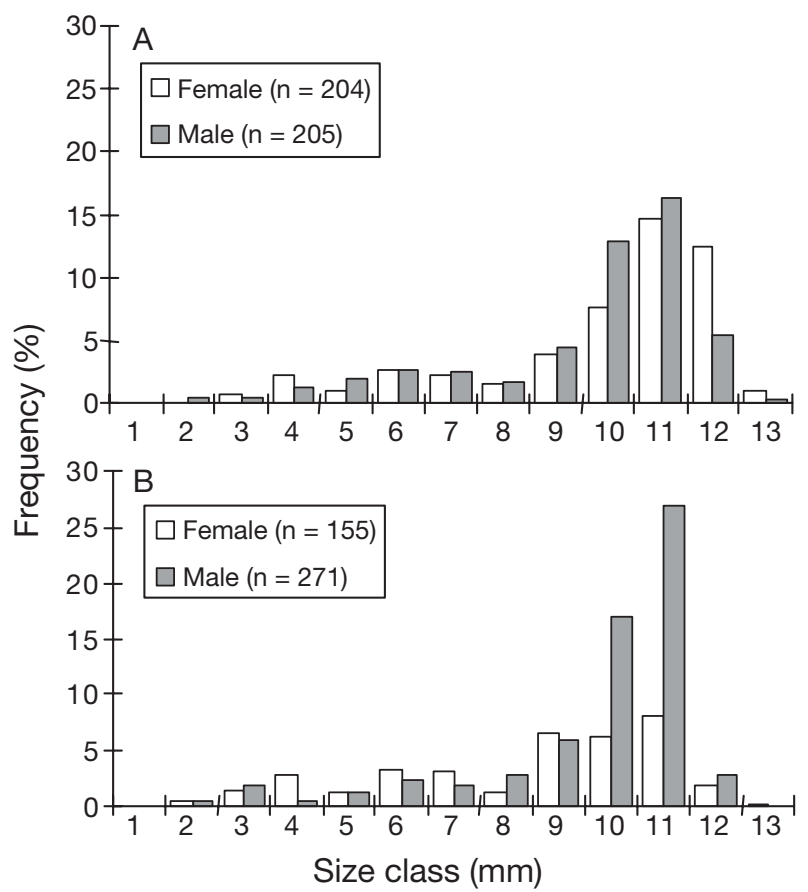

Fig. 5. Argulus coregoni. Size class frequency distribution of female and male parasites on rainbow trout Oncorhynchus mykiss (A) before and (B) after a rapid shaking of fish with a hand net in a salted water container $(5 \% \mathrm{NaCl})$. To obtain sufficient number of parasites, all specimens were collected from 2 randomly chosen fish before the treatment and from 10 fish after the treatment

\section{Selection of methods for control of parasite eggs}

Treatments affected the hatching success of Argulus coregoni eggs (Kruskal-Wallis test for Set A eggs: $\chi^{2}=$ 26.106, df $=5, \mathrm{p}<0.001$; Kruskal-Wallis test for Set B eggs: $\chi^{2}=12.086$, df $=4, p=0.017$; Fig. 6). Compared to controls, a smaller proportion of eggs hatched from clutches that were treated with formalin either applied to eggs that had been allowed to dry over a period of $15 \mathrm{~h}$ or to moist eggs and from clutches that were allowed to dry over periods of 48 or $96 \mathrm{~h}$ (all pairwise comparisons: $\mathrm{p}<0.05)$. A tendency for hatch suppression was also apparent among egg clutches allowed to dry over $24 \mathrm{~h}$; however, the difference was nonsignificant ( $p>0.05$; Fig. 6). Drying over a period of $15 \mathrm{~h}$, potassium permanganate or sodium chloride treatments did not affect the hatching success of parasite eggs (all pairwise comparisons: $\mathrm{p}>0.05$ ).

\section{DISCUSSION}

Modern fish culture is generally conducted under high stocking densities, a favourable environment for transmission and reproduction of parasites. High abundance of parasites inevitably leads to an armsrace between farmers and pathogen; farmers seek new control methods while treatments applied are selecting for tolerance and resistance among parasites (e.g. Lahav et al. 1962, Jones et al. 1992). Instead of using a limited set of chemical treatments against parasites, developing and implementing IPM programs would be a move towards more sustainable and cost-effective fish farming. According to principles of the IPM concept, a parasite control program should be based on an understanding of parasite ecology, and should rest on several pillars including (1) prevention of infections, (2) monitoring infection levels, (3) using thresholds for action, and finally (4) implementing various control tactics.

Prevention is fundamental to IPM and reduces the likelihood of a parasite becoming a problem. Fish culture practices are likely to have a key role in reducing and preventing problems caused by fish lice. Most importantly, destruction of parasite eggs in fish ponds before restocking of fish breaks the life cycle of the parasite by eliminating or reducing the infestations (see below). Prevention of contacts between farmed and wild fish is also an important preventative practice against fish lice, as it is known that parasitic infections of farmed fish are most typically derived from wild fish (Valtonen \& Koskivaara 1994). An additional important

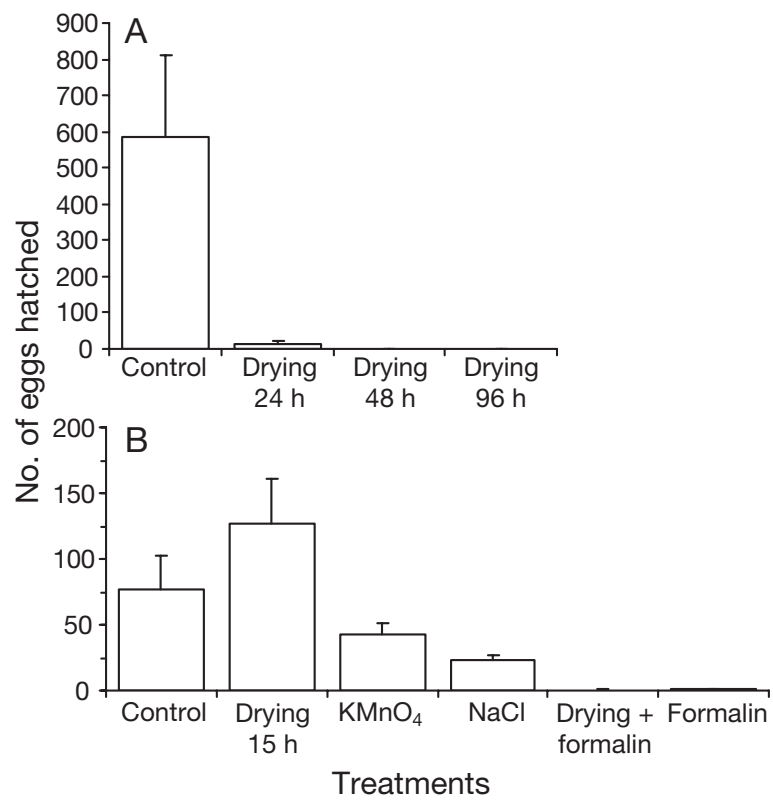

Fig. 6. Argulus coregoni. Mean (+1 SE) number of larvae hatched from eggs exposed to various chemical treatments or to drying. Experiments were performed with parasite eggs collected from a fish farm either on (A) 27 May 1999 or (B) 25 April 2001. During the experiments, eggs were treated while attached to stones, but subsequently they were scraped off stones to balance the numbers of eggs among treatments 
source of infection can be adjacent fish ponds that are infested with fish lice. Thus, self-contained water circulation in each pond may help to prevent the transmission of the parasite between farming sites. The infection can be transmitted via free-swimming louse stages that may live several days without a host (Hakalahti et al. 2005, Bandilla et al. 2008). Some other methods that have the potential to decrease the growth potential of Argulus populations include good fish husbandry leading to less stressed fish (see review on host-parasite interactions by Walker et al. 2004, Bandilla et al. 2005) and alteration of physico-chemical conditions of the farming system. Along with other aquatic parasites (see Chubb 1977), fish lice are greatly affected by abiotic factors in their environment. Several authors have demonstrated the importance physico-chemical properties of water such as oxygen content and $\mathrm{pH}$ for the success of Argulus populations (Pettersen et al. 2006, Mikheev et al. 2007). Habitat requirements of different fish louse species also differ from each other; A. coregoni occurs in large lakes and rivers, mainly on salmonids, whereas $A$. foliaceus is a common generalist in eutrophic, slow-flowing or still waters (Kennedy 1974, Shimura 1983, Taylor et al. 2006).

A subsequent (though not separate) step in the implementation of an IPM program is the monitoring of parasite infection levels. In the case of Argulus coregoni, monitoring might involve direct and indirect means: field sampling to make counts of lice on individual fish or assessment of damage caused by the lice, and the use of trapping devices. As the transmission of A. coregoni to fish is strongly temperature dependent and only takes place during the ice-free period, the monitoring period is relatively short, but should start before the temperature exceeds $10^{\circ} \mathrm{C}$ in spring (Hakalahti \& Valtonen 2003, Hakalahti et al. 2006). We also recommend monitoring of parasite egg numbers, which can be undertaken by placing removable artificial egg laying substrata near the bottom of water ponds (Hakalahti et al. 2004b; see also below). Complete control of $A$. coregoni is neither necessary for high yields nor appropriate for IPM. Fish can tolerate a certain level of louse infestation without appreciable effects on vigor (Bandilla et al. 2006). However, in contradiction, there is a link between Argulus infections and susceptibility to certain harmful microbial diseases (e.g. Cusack \& Cone 1986, Singhal et al. 1990, Bandilla et al. 2006) leading to a reduced acceptable parasite infection levels on fish. The economic threshold for fish louse infestations still needs to be determined, and is likely to vary between different types of culture systems. Rather than waiting for the damage to become apparent, application of control measures should supplement preventative measures when the predeter- mined threshold for action has been reached. A control strategy may be based on a combination of chemical, mechanical, biological and cultural treatments.

Mathematical host-parasite population models can provide insights into the relative importance of factors influencing parasite population dynamics, and can be utilized in the development of effective and targeted control against the parasites (Hudson et al. 2002). Recently, a model based on detailed studies of the life cycle of Argulus coregoni was applied to simulate its population dynamics in Finnish fish farming conditions (Fenton et al. 2006). The model showed that A. coregoni infection level largely relies on the number of eggs in the egg-bank (see Hakalahti et al. 2004c concerning extended hatching of parasite eggs), and destroying eggs with all available means would greatly reduce the size of the parasite population (Fenton et al. 2006). The model showed that the next most effective control of $A$. coregoni may be achieved by targeting juvenile stages attached to fish (Fenton et al. 2006)

Draining and drying of egg laying sites of Argulus spp. has been suggested as a useful method for controlling eggs of the parasite (Bauer 1962). Some authors (Chen 1933, Hoffman 1980) recommend that drying should be accompanied by lime application. We quantified the hatching success of $A$. coregoni eggs in relation to drying period and determined a minimum period of $48 \mathrm{~h}$ needed to eradicate parasite eggs. A high mortality rate was also achieved by exposing the eggs directly to formalin. As complete dehydration of earth-lined ponds is time-consuming and uncertain, some fish farmers in Finland have covered the bottoms of ponds with PVC tarpaulins to facilitate drying and cleaning. Another useful method might be freezing of drained ponds during winter (T. Hakalahti-Sirén unpubl. data). In recent years, there has been increasing interest in using behaviour manipulation as a management tactic against crustacean parasites, and promising results have emerged from experiments in which artificial substrata were used to attract $A$. foliaceus and $A$. coregoni females and to trap their eggs (Gault et al. 2002, Hakalahti et al. 2004b). As the present results show, collected eggs can be effectively destroyed with minimal environmental impact simply by allowing the substrata to dry out. The eggs may also be destroyed after dislodgement with a brush or pressurized water.

Based on literature, currently used control methods against Argulus populations are largely based on the use of limited variety of chemicals, for example potassium permanganate, organophosphates and emamectin benzoate (e.g. Kabata 1985, Hakalahti et al. 2004a, Toksen 2006). The harmful effect of organophosphates to the environment is now widely recog- 
nized, and many countries prohibit their use. In contrast, use of the in-feed treatment formulation SLICE ${ }^{\circledR}$ (in which emamectin benzoate is the active ingredient) is becoming more widespread. It has proven a very effective way to eliminate $A$. coregoni attached to fish (Hakalahti et al. 2004a), but its long-term usefulness is unknown due to a potential for tolerance development. Therefore, the medicine should only be used in response to heavy infestations after other types of controls have failed. However, of all chemicals (sodium chloride, formalin, potassium permanganate and malachite-green/formalin mixture) that were tested in the present study as means to kill parasites, only potassium permanganate was found useful.

The minimum dose of potassium permanganate which led to $100 \%$ mortality among exposed Argulus coregoni was $10 \mathrm{mg} \mathrm{l}^{-1}$ over $30 \mathrm{~min}$. In previous studies a potassium permanganate concentration $1.3 \mathrm{mg} \mathrm{l}^{-1}$ applied as 2 subsequent treatments in $3 \mathrm{~d}$ was found to be effective in controlling $A$. indicus and $A$. japonicus infections on carp (Jafri \& Ahmed 1994), and a concentration $0.5 \mathrm{mg} \mathrm{l}^{-1}$ resulted in a $60 \%$ decrease in the level of A. indicus infection (Singhal et al. 1986). In the present study, only treatments with potassium permanganate concentrations $>1 \mathrm{mg} \mathrm{l}^{-1}$ significantly increased mortality of $A$. coregoni. Some studies have also recommended potassium permanganate concentrations as high as $1 \mathrm{~g} \mathrm{l}^{-1}$ over 5 to $10 \mathrm{~min}$ for controlling of Argulus populations (Christensen 1989). The high variation in recommended dosing with potassium permanganate reflects its variability by water quality as an effective anti-parasite treatment, a property that also makes it a difficult and potentially deleterious treatment to use. Potassium permanganate functions as a strong oxidizing agent that reacts with any material it comes into contact with. Thus, the efficacy of the chemical is related to the amount of reducing substances (e.g. algae, detritus, inorganic reducing substances) in the water, and the amount of permanganate that is quickly reduced to manganese dioxide is called the potassium permanganate demand of the water (see Tucker 1989, Boyd 1990). The efficient use of potassium permanganate requires determination of water potassium permanganate demand before treatment. The oxidizing activity of potassium permanganate is also the primary problem for treated fish and, therefore, a careful choice of the treatment dose is essential to prevent fish mortality. It is advisable for a fish farmer to run a bioassay before treating large numbers of fish with potassium permanganate, as fish tolerance is dependent on many factors such as water $\mathrm{pH}$, temperature, exposure time and the fish species (Marking \& Bills 1975).

The present ban to use malachite green in aquaculture does not seem to explain increased incidences of
Argulus spp. infections since the malachite green/formalin mixture was not sufficiently effective in killing A. coregoni. Other chemicals previously used as bath treatments against argulids include salt $(\mathrm{NaCl})$ and formalin (Kabata 1985). Fish farmers in Finland generally use 10 to $20 \mathrm{~g} \mathrm{l}^{-1}$ sodium chloride solution over a period of 20 to $60 \mathrm{~min}$ against Chilodonella ciliates on fish (Rintamäki et al. 1994). According to Singhal et al. (1986), dipping of infested fish in $30 \mathrm{mg} \mathrm{l}^{-1}$ sodium chloride for 2 to $5 \mathrm{~min}$ is very effective treatment against $A$. indicus. However, in the present study, $20 \mathrm{~g}$ $\mathrm{l}^{-1}$ salt bath over a period of $24 \mathrm{~h}$ did not affect survival of A. coregoni. Also, formalin bath treatments $(0.12 \mathrm{ml}$ $\mathrm{l}^{-1}$ ) are used extensively to control some external protozoan infections of fish (Jørgensen \& Buchmann 2007). In the present study, a relatively high formalin concentration $\left(0.6 \mathrm{ml} \mathrm{l}^{-1}\right)$ did not increase mortality of A. coregoni juveniles or adults.

Surprisingly high numbers of Argulus coregoni and A. foliaceus ( $>80 \%$ of original) were dislodged from fish through shaking them in hand nets in a water container. The detachment rate of $A$. coregoni depended on parasite sex and size, dislodgement rates of gravid females being especially pronounced. Detachment of females may explain the difference in dislodgement between the sexes, because remaining on a host during disturbance is likely to be risky for breeding females. In addition, many of the females were ready to lay their eggs on the bottoms of ponds (Mikheev et al. 2001, Hakalahti et al. 2004b). The observed difference by parasite sex may also be explained by weight differences; egg carrying females sank faster than males of the same body length (authors' unpubl. data). Application of mechanical treatments, however, is not an advisable response to low fish louse infection levels as they would elicit stress reactions and scale loss in fish, increasing their susceptibility to other diseasecausing agents (e.g. Pickering \& Pottinger 1989). Nevertheless, on a small scale, shaking could be used in response to heavy infections, e.g. when other treatment options are limited or when done in connection with normal fish husbandry practices (fish grading, vaccination, transfer etc.) and in conformity with animal welfare guidelines. When infested fish are treated mechanically or transferred between aquaculture units, the water must be collected and sieved or treated in order to kill parasites. To our knowledge, no other biological methods (e.g. cleaner fishes; see Bandilla et al. 2008 concerning predation by fish on A. coregoni) besides behavior manipulation and desiccation of eggs have been applied to reduce Argulus numbers in aquaculture. Cultural control methods could include fallowing, i.e. maintenance of host-free seasons, which certainly would diminish the parasite population size, but not necessarily break the life cycle of the parasite 
due to diapausing eggs (see Mikheev et al. 2001, Hakalahti et al. 2004c).

Here, we present a framework for sustainable management of Argulus coregoni populations. Financial losses caused by the fish lice would be best tackled by implementing preventative control methods. However, to make this applicable, further investigation is required to establish factors affecting the growth potential of fish louse populations. Another essential part of managing Argulus populations would be the regular monitoring of louse infection levels. When the threshold level for louse infection has been reached, intervention by applying control treatments is needed to prevent extensive damage caused by the parasite. The use of multiple tactics and rotation of treatments is a preferable and, in most cases, also a possible option for managing Argulus populations. Such an approach would mitigate the development of parasite tolerance towards chemical and medical treatments (e.g. SLICE ${ }^{\circledR}$, emamectin benzoate) currently available for the control of fish lice. The present experiments showed that $A$. coregoni can be controlled effectively by draining and drying of parasite egg laying sites. If not possible, another effective means was treatment of eggs with formalin. The experiments also showed that parasite juveniles and adults were susceptible to treatments with potassium permanganate. Shaking fish in a hand net also resulted in large decreases in the numbers of mature fish lice on fish.

Acknowledgements. This research was funded by the Emil Aaltonen Foundation, Georg and Ella Ehrnrooth Foundation (T.H.-S.), Finnish Academy and Russian Foundation for Basic Research (project 08-04-00893 to V.N.M.).

\section{LITERATURE CITED}

Bakke TA, Harris PD (1998) Diseases and parasites in wild Atlantic salmon (Salmo salar) populations. Can J Fish Aquat Sci 55:247-266

> Bandilla M, Hakalahti T, Hudson PJ, Valtonen ET (2005) Aggregation of Argulus coregoni (Crustacea: Branchiura) on rainbow trout (Oncorhynchus mykiss): a consequence of host susceptibility or exposure? Parasitology 130 169-176

Bandilla M, Valtonen ET, Suomalainen LR, Aphalo P, Hakalahti T (2006) A link between ectoparasite infection and susceptibility to bacterial disease in rainbow trout. Int J Parasitol 36:987-991

Bandilla M, Hakalahti-Sirén T, Valtonen ET (2008) Patterns of host switching in the fish ectoparasite Argulus coregoni. Behav Ecol Sociobiol 62:975-982

Bauer ON (1962) Parasites of freshwater fish and the biological basis for their control. Bull State Sci Res Inst Lake River Fish Leningrad 49:3-215 (in Russian) available in translation: Israel Program for Scientific Translations, Silvan Press, Jerusalem

Boyd CE (1990) Water quality in ponds for aquaculture. Alabama Agricultural Experiment Station, Auburn Uni- versity, Auburn, AL

Bron JE, Sommerville C, Wootten R, Rae GH (1993) Fallowing of marine Atlantic salmon, Salmo salar L., farms as a method for the control of sea lice, Lepeophtheirus salmonis (Kroyer, 1837). J Fish Dis 16:487-493

Chen T (1933) A study on the methods of prevention and treatment of fish lice in pond culture. Lignan Sci J 12: 241-244

Christensen MS (1989) The intensive cultivation of freshwater fish in cages in tropical and subtropical regions. Anim Res Dev 29:7-20

Chubb JC (1977) Seasonal occurrence of helminths in freshwater fishes. Part I. Monogenea. Adv Parasitol 15:133-199

Costello MJ (1993) Review of methods to control sea lice (Caligidae: Crustacea) infestations on salmon farms. In: Boxshall GA, Defaye D (eds) Pathogens of wild and farmed fish: sea lice. Ellis Horwood, Chichester, p 219-252

Costello MJ (2006) Ecology of sea lice parasitic on farmed and wild fish. Trends Parasitol 22:475-483

Cusack R, Cone DK (1986) A review of parasites as vectors of viral and bacterial diseases of fish. J Fish Dis 9:169-171

Duston J, Cusack RR (2002) Emamectin benzoate: an effective in-feed treatment against the gill parasite Salmincola edwardsii on brook trout. Aquaculture 207:1-9

Fenton A, Hakalahti T, Bandilla M, Valtonen ET (2006) The impact of variable hatching rates on parasite control: a model of Argulus coregoni in a Finnish fish farm. J Appl Ecol 43:660-668

Gault NFS, Kilpatrick DJ, Steward MT (2002) Biological control of the fish louse in a rainbow trout fishery. J Fish Biol 60:226-237

Hakalahti T, Valtonen ET (2003) Population structure and recruitment of the ectoparasite Argulus coregoni Thorell (Crustacea: Branchiura) on a fish farm. Parasitology 127:79-85

Hakalahti T, Lankinen Y, Valtonen ET (2004a) Efficacy of emamectin benzoate in the control of Argulus coregoni (Crustacea: Branchiura) on rainbow trout. Dis Aquat Org 60:197-204

- Hakalahti T, Pasternak A, Valtonen ET (2004b) Seasonal dynamics of egg laying and egg-laying strategy of the ectoparasite Argulus coregoni (Crustacea: Branchiura). Parasitology 128:655-660

Hakalahti T, Häkkinen H, Valtonen ET (2004c) Ectoparasitic Argulus coregoni hedge their bets - studies on egg hatching dynamics. Oikos 107:295-302

Hakalahti T, Bandilla M, Valtonen ET (2005) Delayed transmission of a parasite is compensated by accelerated growth. Parasitology 131:647-656

- Hakalahti T, Karvonen A, Valtonen ET (2006) Climate warming and disease risks in temperate regions-Argulus coregoni and Diplostomum spathaceum as case studies. J Helminthol 80:93-98

Hoffman GL (1980) Parasitic diseases of laboratory fishes and their control. J Fish Dis 3:348-352

Hoy MA (1998) Myths, models and mitigation of resistance to pesticides. Philos Trans R Soc Lond B Biol Sci 353: $1787-1795$

Hudson PJ, Rizzoli A, Grenfell BT, Heesterbeek H, Dobson AP (2002) The ecology of wildlife diseases. Oxford University Press, Oxford

Jafri SIH, Ahmed SS (1994) Some observations of mortality in major carps due to fish lice and their chemical control. Pak J Zool 26:274-276

- Jones MW, Sommerville C, Wootten R (1992) Reduced sensitivity of the salmon louse, Lepeophtheirus salmonis, to the 
organophosphate dichlorvos. J Fish Dis 15:197-202

Jørgensen TR, Buchmann K (2007) Stress response in rainbow trout during infection with Ichthyophthirius multifiliis and formalin bath treatment. Acta Ichtyol Pisc 37:25-28

Kabata Z (1985) Parasites and diseases of fish cultured in tropics. Taylor \& Francis, London

Karvonen A, Savolainen M, Seppälä O, Valtonen ET (2006) Dynamics of Diplostomum spathaceum infection in snail hosts at a fish farm. Parasitol Res 99:341-345

Kennedy CR (1974) A checklist of British and Irish freshwater parasites with notes on their distribution. J Fish Biol 6 613-644

Lahav M, Shilo M, Sarig S (1962) Development of resistance to lindane in Argulus populations of fish ponds. Bamidgeh $14: 67-76$

Lee ET (1992) Statistical methods for survival data analysis John Wiley \& Sons, Hoboken, NJ

Marking LL, Bills TD (1975) Toxicity of potassium permanganate to fish and its effectiveness for detoxifying antimycin. Trans Am Fish Soc 104(3):579-583

Menezes J, Ramos MA, Pereira TG, Moreira de Silva A (1990) Rainbow trout culture failure in a small lake as a result of massive parasitosis related to careless fish introductions. Aquaculture 89:123-126

Mikheev VN, Valtonen ET, Rintamäki-Kinnunen P (1998) Host searching in Argulus foliaceus L. (Crustacea: Branchiura): the role of vision and selectivity. Parasitology 116:425-430

Mikheev VN, Pasternak AF, Valtonen ET, Lankinen Y (2001) Spatial distribution and hatching of overwintered eggs in a fish ectoparasite Argulus coregoni Thorell (Crustacea: Branchiura). Dis Aquat Org 46:123-128

Mikheev VN, Pasternak AF, Valtonen ET (2007) Host specificity of Argulus coregoni (Crustacea: Branchiura) increases at maturation. Parasitology 134:1767-1774

Mordue (Luntz) AJ, Pike AW (2002) Integrated pest management in salmon farming. Pest Manag Sci 58:513-629

Mustafa A, Speare DJ, Daley J, Conboy GA, Burka JF (2000) Enhanced susceptibility of seawater cultured rainbow trout, Oncorhynchus mykiss (Walbaum), to the microsporidian Loma salmonae during a primary infection with a sea louse, Lepeophtheirus salmonis. J Fish Biol 23 337-341

Pasternak A, Mikheev V, Valtonen ET (2004) Growth and development of Argulus coregoni (Crustacea: Branchiura) on salmonid and cyprinid hosts. Dis Aquat Org 58: 203-207

Pettersen RA, Vøllestad LA, Flodmark LEW, Poléo ABS (2006) Effects of aqueous aluminium on four fish ectoparasites. Sci Total Environ 369:129-138

> Pickering AD, Pottinger TG (1989) Stress responses and disease resistance in salmonid fish: effects of chronic elevation of plasma cortisol. Fish Physiol Biochem 7:253-258

Rahman M (1996) Effects of freshwater fish parasite, Argulus foliaceus Linn. infection on common carp Cyprinus carpio. Bangladesh J Zool 65:2793-2798

Rintamäki P, Torpström H, Bloigu A (1994) Chilodonella spp. at four fish farms in northern Finland. J Eukaryot Microbiol 41:602-607

Rintamäki-Kinnunen P, Valtonen ET (1997) Epizootiology of protozoans in farmed salmonids at northern latitudes. Int J

Editorial responsibility: David Marcogliese,

Montréal, Québec, Canada
Parasitol 27:89-99

Rintamäki-Kinnunen P, Rahkonen M, Mannermaa-Keränen AL, Suomalainen LR, Mykrä H, Valtonen ET (2005a) Treatment of ichthyophthiriasis after malachite green. I. Concrete tanks at salmonid farms. Dis Aquat Org 64: 69-76

Rintamäki-Kinnunen P, Rahkonen M, Mykrä H, Valtonen ET (2005b) Treatment of ichthyophthiriasis after malachite green. II. Earth ponds at salmonid farms. Dis Aquat Org $66: 15-20$

Shimura S (1981) The larval development of Argulus coregoni Thorell (Crustacea: Branchiura). J Nat Hist 15:331-348

Shimura S (1983) Seasonal occurrence, sex ratio and site preference of Argulus coregoni Thorell (Crustacea: Branchiura) parasitic on cultured freshwater salmonids in Japan. Parasitology 86:537-552

Singhal RN, Jeet S, Davies RW (1986) Chemotherapy of six ectoparasitic diseases of cultured fish. Aquaculture $54: 165-171$

Singhal RN, Jeet S, Davies RW (1990) The effects of argulosissaprolegniasis on the growth and production of Cyprinus carpoi. Hydrobiologia 202:27-31

Sommerville C (1998) Integrated control-an example: sea lice of Atlantic salmon. Parasitol Int 47:85

Stone J, Sutherland IH, Sommerville C, Richards RH, Varma KJ (2000) Field trials to evaluate the efficacy of emamectin benzoate as an oral treatment of sea lice, Lepeopthreirus salmonis (Krøyer) and Caligus elongatus (Nordman), infestations in Atlantic salmon, Salmo salar. Aquaculture 186:205-219

Suomalainen LR, Tiirola MA, Valtonen ET (2005) Influence of rearing conditions on Flavobacterium columnare infection of rainbow trout. J Fish Dis 28:271-277

Taylor NGH, Sommerville C, Wootten R (2006) The epidemiology of Argulus spp. (Crustacea: Brachiura) infections in stillwater trout fisheries. J Fish Dis 29:193-200

Toksen E (2006) Argulus foliacesus (Crustacea: Branchiura) infestation on oscar Astronotus ocellarus (Cuvier, 1829) and its treatment. EU J Fish Aquat Sci 23:177-179

Treasurer JW (2002) A review of potential pathogens of sea lice and the application of cleaner fish in biological control. Pest Manag Sci 58:546-558

Tucker CS (1989) Method for estimating potassium permanganate disease treatment rate for channel catfish in ponds. Prog Fish-Cult 51:24-26

Tully O, Nolan DT (2002) A review of the population biology and host-parasite interactions of the sea louse Lepeophtheirus salmonis (Copepoda: Caligidae). Parasitology 124:165-182

Valtonen ET, Koskivaara M (1994) Relationship between the parasites of some wild and cultured fishes in two lakes and a fish farm in central Finland. Int J Parasitol 24: 109-118

Walker PD, Flik G, Wendelaar Bonga SJ (2004) The biology of parasites from the genus Argulus and a review of the interactions with its host. In: Wiegertjes GF, Flik G (eds) Host-parasite interactions. Garland Science/BIOS Scientific Publishers, Oxford, p 107-129

- Willoughby LG, Roberts RJ (1992) Towards strategic use of fungicides against Saprolegnia parasitica in salmonid fish hatcheries. J Fish Dis 15:1-13

Submitted: January 14, 2008; Accepted: July 30, 2008

Proofs received from author(s): September 23, 2008 